New Test. Stud. 57, pp. 153-154. (c) Cambridge University Press, 2011

doi:10.1017/S0028688510000317

\title{
In Memoriam: Rev. Professor Robin McL. Wilson and Professor Graham N. Stanton
}

During the past short while, two former editors of New Testament Studies, who both also became Presidents of SNTS, have sadly passed away, and it is fitting here to pay tribute to them for their very extensive service to the Journal and to the Society to which it is attached.

Robert (Robin) McLachlan Wilson, who spent his entire academic career (1954-1983) at St. Andrew's University, Scotland, was a close friend of his colleague Matthew Black, who was the founding editor of NTS from 1953-1977. Robin Wilson gave considerable editorial assistance to Matthew Black from early on, becoming 'review editor' from 1959, then 'associate editor' from 1967. After serving as 'acting editor' in 1976-1977 he then inherited the role of editor in 1977 , in which he continued through to his retirement in 1983. In those days editing the Journal also involved editorship of the SNTS Monograph Series, and he managed both tasks with exemplary care and attention during a very successful period of growth. He was renowned for his attention to detail, his phenomenal breadth of knowledge, his linguistic expertise, and his helpfulness to authors. Late into his retirement he selflessly offered his assistance to subsequent editors, and no-one could offer wiser or more perceptive advice. The high reputation enjoyed by the Journal and Monograph Series owes much to the standards set in those first formative decades, and Robin Wilson's unobtrusive service to scholarship in this connection was of considerable significance. With regard to SNTS he served for many years on the Committee and Editorial Board (19671983), and was President at the Rome meeting in 1981. He died aged 94 on 27 June 2010, and is remembered with great affection and enormous respect by his international circle of friends, colleagues, and students, as well as those many authors who benefited from his editorial care.

Graham N. Stanton came from New Zealand to the UK, where he studied for a PhD (under C. F. D. Moule) and then taught at King's College London (19701998) and Cambridge (1998-2007) where he was Lady Margaret Professor. With a genius for organisation and the quiet negotiation of potential problems, Graham became Secretary of SNTS (1976-1982) and then editor of NTS and the Monograph Series, in succession to Robin Wilson, from 1983 till 1991. His work-rate, his scholarly wisdom and his encouragement of junior scholars were legendary: somehow he juggled innumerable tasks with never-failing efficiency, 
and he took particular pleasure in seeing the work of up-and-coming scholars through to publication. Unfailingly courteous and kind, he helped many scholars bear the disappointment of rejection by making sure they got positive advice, and his suggestions for revision and improvement of manuscripts were of enormous value. As in his own publications, he set the highest standards of scholarship, to the benefit of us all. He became President of SNTS in 1991 (Strasbourg) and gave tirelessly of his time and energy to foster the work of the Society for many years thereafter. He died aged 69 on 18 July 2009, after a long battle with cancer, but his scholarship, his gentleness of spirit and his warm encouragement of others live on in the memory of all who knew him, not least his many doctoral students.

John Barclay (current editor) 